\title{
Training About Submitting Scientific Articles Through OJS (Online Journal System)
}

\author{
Zulkifli Musannip Efendi Siregar \\ Universitas Labuhanbatu, Rantauprapat, North Sumatera Indonesia. \\ ${ }^{*}$ Corresponding Author: \\ Email: zulkiflimusannipefendi@gmail.com
}

\begin{abstract}
.
The partner in this training was the Faculty of Economics and Business, Universitas Labuhanbatu. The partner's problem was that there were many students who have difficulties regarding the procedure for submitting scientific articles. Therefore, this problem made students difficulty in publishing their scientific work. This training was conducted to transfer knowledge regarding how to submit scientific articles, and also aims to improve students' ability to submit scientific articles. The method used was the lecture method and practice. Approximately 18 students participated in the training. After workshop or training programe, the participants knowledge and skill to submit the article were more improved.
\end{abstract}

Keywords: Workshop, Article, Submit, Online Journal System.

\section{INTRODUCTION}

Nowadays, universities have encouraged students to write scientific articles and publish articles in journals, both in reputable national and international journals. Publication of scientific articles by students is also one of the assessments for the accreditation of a university. Therefore, training in the form of procedures for submitting scientific articles is very important to be held in order to improve student skills in submitting or submitting scientific articles owned by students. Currently, journal management has led to online journaling using OJS or online journal system. According to Arief \& Handoko, (2016) online journals or journals in electronic format are an alternative that can be utilized by journal managers. In addition to the effectiveness of journal management and management, most online journal platforms are also open source and free. One of the online journal platforms that is widely used and quite reliable is OJS (Open Journal System).

Submitting scientific articles is a skill that must be possessed by students and lecturers. This is of course to make it easier for students to publish scientific articles.Prior to the training, the writer conducted a survey by interviewing students about their ability to submit scientific articles. All participants who attended stated that it was difficult to submit scientific articles. Some of the obstacles faced by students are using the online journal system. This is also in line with the opinion of Triyanto et al.,(2020) who found that there are still many students and lecturers who do not understand the system of sending scientific papers in a journal that has an open journal 
system base. Students' misunderstanding in submitting scientific articles will make it difficult for students to submit scientific article manuscripts.

\section{METHODS}

Community service was carried out by conducting training or workshops. The workshop approach makes a positive contribution to writing skills [3]. The methods used are lecture, discussion, and practicum methods. According to Arta, (2019) the lecture method is material provided through reference searches related to the material provided. Meanwhile, the discussion method is a discussion or question and answer session between the presenters and the participants of the scientific article writing training. The target of this scientific article writing training is students at the Faculty of Economics and Business, Universitas Labuhanbatu with a total of 18 participants. This workshop on how to submit scientific articles was held on April 24, 2021, starting from 09.00 to $12.00 \mathrm{WIB}$.

\section{RESULT AND DISCUSSION}

The training or workshop on how to submit scientific articles was held in Universitas Labuhanbatu Postgraduate Program room. The workshop started at 09.30, starting with a speech given by Mr. Pristiyono S.E., M.Si as the dean of the Faculty of Economics and Business, Universitas Labuhanbatu. After giving a speech, it was continued with the delivery of material by Dr. Zulkifli Musannip Efendi Siregar, S.Kom.,M.M. Before doing the submitting process or sending scientific articles. Some things that we must understand is to make sure that we have read the author guideline of the journal that we want to use as a place of publication. Manuscripts of articles must be adapted to the template in the journal.

After we can make sure that our articles are in accordance with the journal's instructions, then we can do the process of submitting our articles.As an initial stage, the resource person first displays the form or appearance of the online journal system, and what are the important components that must be understood by students when they want to send/submit scientific article manuscripts to the journal manager. The first step that students must take is to be able to register in the online journal system. To register, students must have an active email. After successfully registering, then login according to the username and password that has been registered.

After logging in, there are several important steps that must be mastered,namely:

1. First step: Start

2. Second step: Upload Submission

3. Third step: Enter Metadata

4. Fourth step: Upload supplementary files

5. Fifth step: Confirmation 


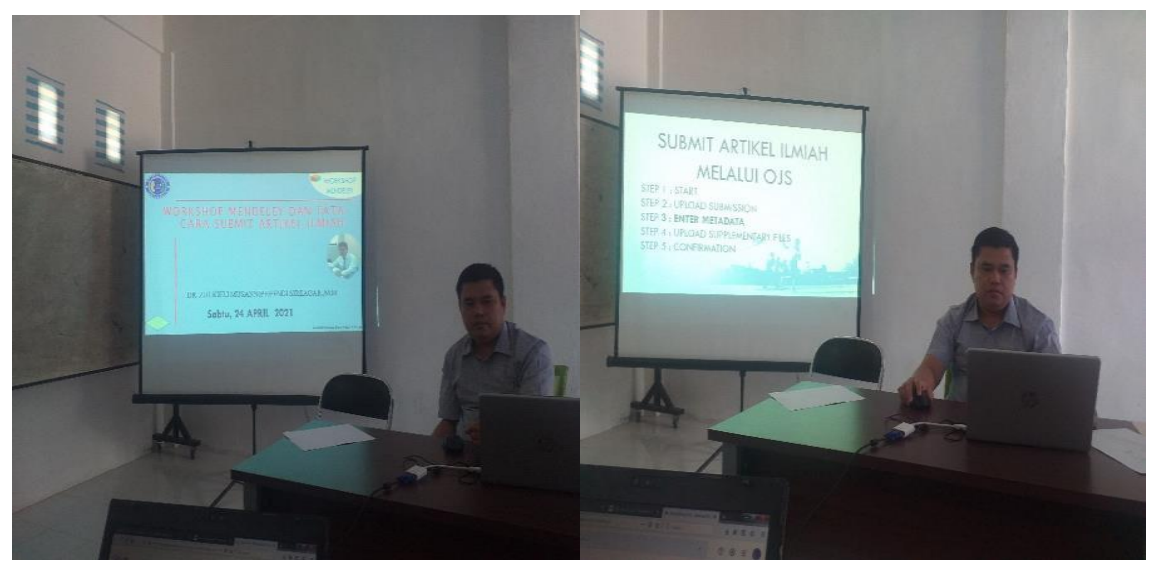

Fig 1. The Training Process explains the steps for submitting scientific articles First step: Start

In the first step, namely start, in this section we will fill out or check the list in the submission checklist. The submission checklist is useful for checking and making sure the articles you want to submit are in accordance with the directions, according to the template, have never been published before, and the file format is as recommended by the journal manager. Therefore, all of the submission checklists must be checked. Next, don't forget to check the privacy statement. If you want to give a message to the editor, you can comment in the comments for editor section. Then click save and continue.

\section{Step Two: Upload submission}

In this second step, uploading scientific article manuscripts that are ready to be published. This can be done in the file submission section, then press choose file / select the manuscript to be uploaded which is stored on the drive. Don't forget every time you finish filling in the data, then click save and continue.

\section{Step three: Enter Metadata}

In the enter metadata section, the data that must be prepared are author data, title and abstract, keywords and references. When finished inputting the required data in the enter metadata section, then click save and continue.

\section{Fourth Step: Upload Supplementary Files}

If there are supporting files for the manuscript that you want to submit to the journal manager, it can be uploaded in the uploading supplementary files section. When finished filling in the data on the upload supplementary files, click save and continue.

\section{Fifth step: Confirmation}

In this step to confirm that we have completed the submit process according to the required data. Before pressing finish, you should recheck the data that has been filled in or uploaded, whether it is correct or there are still errors. If there is an error, it can be corrected. Furthermore, if you are sure with the data filled in, then click finish. 
After conducting the training, the results of the service showed that there was an increase in students' understanding and skills in doing student activities. This result is in line with the findings of the previous service conducted by [5] who do service to SD Tunas Harapan teachers in Patumbak Kampung, Ke. Patumbak, Kab. Deli Serdang. After receiving training, the teachers are generally quite proficient in entering their writings or scientific works in online journals guided by the material provided by the service team.

\section{Documentation of the training program as follows:}
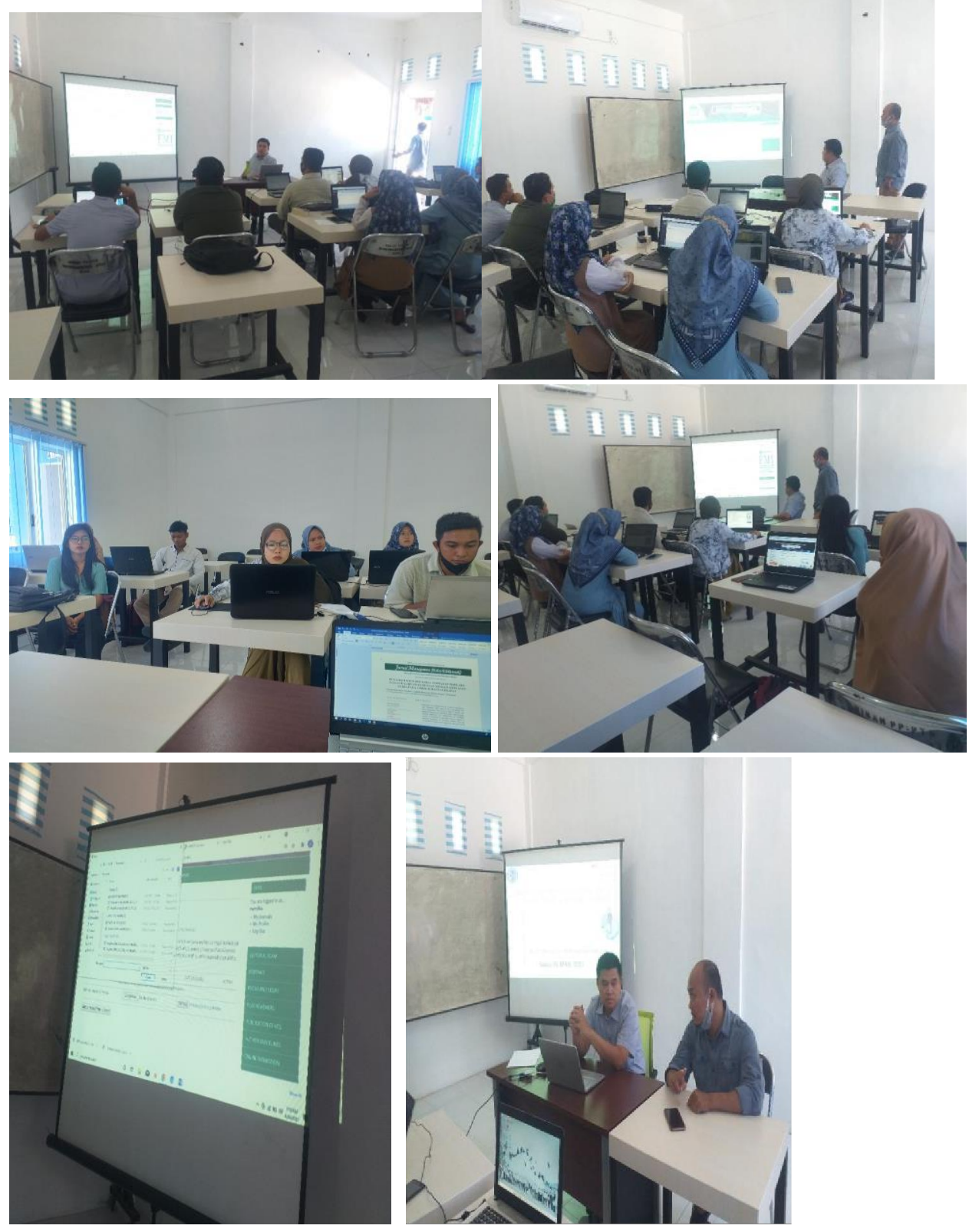

Fig 2. Documentation of Workshop Submitting Article 


\section{CONCLUSION}

Training or workshops that has been conducted for students of the Faculty of Economics and Business, Universitas Labuhanbatu can effectively improve students' abilities in submitting or submitting scientific articles to journals, both international journals and national journals. After conducting the training, partners, in this case students of the Faculty of Economics and Business, Universitas Labuhanbatu have better insight and knowledge about the process of submitting scientific articles.

\section{REFERENCES}

[1] I. Arief and H. Handoko, Jurnal Online dengan Open Journal System. 2016.

[2] T. Triyanto et al., "Transfer Knowledge: Submit Artikel Pada Jurnal Online Berbasis OJS Untuk IPELMAS,” J. Pengabdi. Masy. Darma Bakti Teuku Umar, vol. 2, no. 1, pp. 52-62, 2020.

[3] J. Jasmine and W. Weiner, "The effects of writing workshop on abilities of first grade students to become confident and independent writers," Early Child. Educ. J., vol. 35, no. 2, pp. 131-139, 2007, doi: 10.1007/s10643-007-0186-3.

[4] K. S. Arta, "Pelatihan Penulisan Artikel Untuk Publikasi Di Jurnal Ilmiah Untuk Meningkatkan Profesionalisme Bagi Guru-Guru Di Kecamatan Kubutambahan Kabupaten Buleleng," Acarya Pustaka, vol. 5, no. 2, p. 17, 2019, doi: 10.23887/ap.v5i2.17412.

[5] F. I. Butsi and A. Nasution, "Pelatihan Tips Dan Trik Submit Artikel Ilmiah Di Jurnal Berbasis Online," Amaliah J. Pengabdi. Kpd. Masy., vol. 1, no. 1, pp. 49-51, 2017, doi: 10.32696/ajpkm.v1i1.16. 